\title{
Rumford and the Royal Institution: A Retrospect.
}

\author{
By T. E. JAMES.
}

$\mathrm{B}^{\mathrm{H}}$ ENJAMIN THOMPSON, knighted by George III., and created Count von Rumford by the Elector Palatine of Bavaria as a reward for his services, was born at North Woburn, Massachusetts, on March 26, 1753, and he died at Auteuil, near Paris (where he had settled), on Aug. 21, 1814, aged sixty-one years. His career in early youth was a response, as in many other instances in a new colony, to the varied and often lowly occupations near at hand. For a time hewas in the medical faculty at Harvard, and he also engaged in schoolmastering. No one could have foretold that he stood on the threshold of events from which emerged, as if preordained, the governing factors of his life. A matrimonial venture at twenty soon ended in convenient separation. There was a child of the union.

Thompson was a major of New Hampshire militia when the American War of Independence broke out, but he became suspect as one showing "unfriendliness to the cause of liberty'. Removing to Boston (or shall we say escaping?), he was arraigned there; finally he cleared himself of the charges against him. In 1776 Boston was evacuated and Thompson's selection to carry the news to England confirmed his

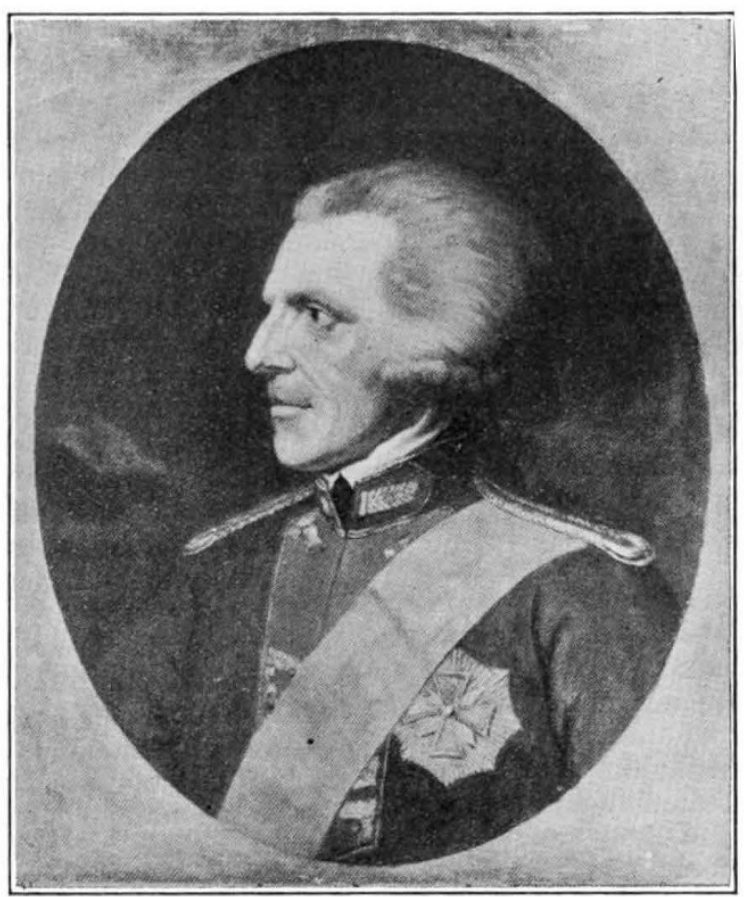

FIt. 1.-Count von Rumford, F.R.S. From the painting after Moritz Kellerhoven, in the National Portrait Gallery, London.
In 1784, Sir Benjamin Thompson, newly knighted, entered on a completely novel mode of life. The Elector Charles Theodore of Bavaria pressingly solicited his services at Munich to initiate schemes in mitigation of social and economic disorders in his dominions. Leave of George III. having been obtained, our soldier-philosopher set forth, actually remaining at Munich for ten to eleven years-the keystone of the arch of progress being military persuasion, to use a mild word, in co-operation with civil authority. Suffice that, as an apostle of order, he routed chaos. Meantime his philosophical studies were pursued, coupled with a vast output of political and economic writings. The following unpublished letter (in holograph *) will, perhaps, be of interest, as indicating two kinds of leanings :

MUNICH, 10th May, 1797. Gentlemen, I send you herewith my Seventh Essay, $\dagger$ which I shall be glad to see published as soon as possible. You will send me 12 copies of it (through Mr. James Meyer of Leaden-hall Street) as soon as it is out of the press. You will please to send me at the same time - or- rather immediately on the receipt of this letter -a collection of all the Pamphlets that have been published on the subject of Mr. Pitt's Bill for making better provision for the Poor. You will direct Mr. Meyer to order his allegiance to the mother-country. In favour here, he occupied a post in the Colonial Office, becoming afterwards an under-secretary (1780), charged with military duties relating to the British forces. Next, he appeared in service in America as a lieutenantcolonel in George III.'s American Dragoons. Returning to England in 1783 (then thirty years of age), he retired on half pay, with the rank of colonel.

So far, vicissitudes had had triumphant and material issues. Thompson's record as an experimental philosopher begins during these latter periods. It forms a chapter by itself, too diverse for inclusion here. However strange it may seem, he had been familiar with the discoveries and implications of contemporary science. They did not attract him as diversions, but met natural promptings. In 1779 he was elected a fellow of the Royal Society and in 1792 he received the Copley Medal. Later (1799), he was a member of Council of the Society.

No. 3229, VoL. 128]
Correspondent at Flamborough to forward these articles to me immediately by the Diligence, addressed to myself at Munich.

I have hitherto been prevented from sending you my Essay on the "Construction of Kitchen fireplaces" by an earnest desire to make that Publication as perfect as possible. I have hopes however of being able to forward it to you in a few weeks.

I am, with much Regard and Esteem, Gentlemen,

$$
\text { Yours most sincerely, }
$$

RUMFORD.

Messrs. Cadel, jun r. \& Davies, London.

P.S.-You will please to make presents in my name of the Seventh Essay to all those to whom I requested Presents might be made of my Sixth.

\section{Before returning from Bavaria it was sought to}

* Archives, Patent Office Library. By courtesy of the Librarian. $\dagger$ Essay VII, "Of the Propagation of Heat in Fluids", is prefaced sophical investigations, than to take anything for granted", 
make Count von Rumford a Minister at the English Court, representing Bavaria. Rejection was emphatic. He was a British-born subject. Thereupon the Count resumed residence in London as a private citizen. The rebuff had unsettling elements; he entertained the idea of a domicile in America, but gave it up, and certainly there were difficulties, for he had incurred legal disabilities. In the end, America saw him no more, although his fame had crossed the ocean, and had received ample recognition.

It was at this time that Count Rumford published his historic suggestions which ultimately formed the basis upon which the Royal Institution was founded in 1799. Drawn up in pamphlet form extending to 50 pages, this issue was widely circulated in North America and elsewhere.* The title ran thus :

"Proposals for forming by Subscription in the Metropolis of the British Empire A Public Institution for diffusing the knowledge and facilitating the general introduction of Useful Mechanical Inventions and Improvements, and for teaching, By courses of Philosophical Lectures and Experiments, The Application of Science to the Common Purposes of Life."

In 1802, Rumford left England for Paris, never revisiting us. To everyone's surprise, he married, in 1805, Mme. Lavoisier, widow of the great chemist, but a separation followed in 1809 . His daughter's comment on this venture referred to it as a bold, imprudent step, completing many vexations. By now the strain of military duties had, without doubt, weakened his bodily powers ; maybe in some degree his faculties.

Posterity must envisage many blanks and imperfections in any real biographical estimate of this remarkable man. Rumford was more than a dual personality in whose study on that basis the springs of conduct could receive adjustment. A restless youth, followed by moods of militarism, was the ally throughout of a natural philosophical bias. The latter did not, however, tutor the senses, or restrain a riot of philanthropic fancy and effort. Could he have made philosophy the dominating influence, eschewed certain illusions and reaffirmations made in middle life, a calm and dignified passage into that older state which has finality in sight might have been prophesied with some approach to certainty. But it was otherwise.

\section{RUMFORD's GIFTS FOR SCIENCE.}

Allusion may be made at this point to a period in Rumford's life when he made certain endowments for scientific purposes, applicable in England and in America. Writing to Sir Joseph Banks in July 1796, he intimated his desire to establish a prize medal in gold (with silver replica) in recognition of studies in the philosophy of heat or light, the awards to rest with the Royal Society of London. Whether preliminary discussions on the subject

* No copy of this pamphlet exists at the Roval Institution. In 1870 it was reprinted for issue in the Proceedings, from a copy at Althorp. There is also one in the British Museum. An original and complete copy of the pamphlet may be seen in the Patent Office Library, bound in at the end of an octavo set of Rumford's Essays, London edition.

No. 3229, VoL. 128] had taken place with Banks is not known. But by that time Rumford had been a fellow of the Society for seventeen years. He had bid farewell to Munich, was again visiting London, enjoying its scientific life-as witness, he dined twice at the Royal Society Club in 1796. The terms of this Rumford gift need not be recapitulated; but it may be noted that the original design for the medal (1797) did not bear the effigy of Rumford. This early pattern was abolished in Victorian times and the portrait-head of Rumford adopted in perpetuity for the obverse of the medal.* The initial allotment was made to Rumford himself in 1802 and as for the year 1800 ; he did not receive it until 1804, when it was sent to him at Paris by the hand of the president, Sir Joseph Banks- "the first opportunity I have had, though decreed a year and a half ago ", wrote Banks. The American Academy of Arts and Sciences received on the same date as the Royal Society a similar offer, addressed to John Adams, covering 5000 dollars, but restricted to researches made in " any part of the continent of America, or in any of the American Islands". They placed the bust of Rumford, in uniform, on the medal, which the English Society could not, in all the circumstances, have done. The Academy's first award was not made until 1839 .

\section{Beginnings of the Royal Institutron.}

It is recorded that on June 29, 1799, at a meeting of the Managers of the new foundation, the Earl of Winchilsea, as president, acquainted them that he had had the honour of mentioning it to His Majesty King George III., who had been graciously pleased to honour it with his patronage, and to allow it to be called the Royal Institution. It was incorporated on Jan. 20, 1800, and arms, crest, and supporters were granted on Jan. 31.

George Finch, ninth Earl of Winchilsea and fifth Earl of Nottingham, who was chosen first president, occupied a position confirmed and retained for fourteen years. Since he was not, in the precise sense, a man of science, we are referred to general considerations, and those of a personal nature, as justification for such marked and extended confidence. Doubtless he was an acceptable colleague in Rumford's view, on the ground of events in the Earl's career, parallel in certain respects with those in his own. Born at St. James's, Westminster, in 1752, and educated at Eton and Christ Church, Oxford, George Finch succeeded to the peerage in 1769. He died in London on Aug. 2, 1826, aged seventy-three years, bearing the contemporary reputation of being " a nobleman of the old school and a high bred gentleman in his manners". Burley-on-the-Hill, Oakham, Rutlandshire, was the family seat and the Earl became, in course of time, lord-lieutenant of the county.

The American War of Independence found Winchilsea a staunch adherent of George III. He made Rutland an intensive recruiting area for an

* Ellis, "Life of Rumford" (1873), says that the head of Rumford on the Royal Society's Medal is from a portrait of him painted in Munich which hung in his house at Brompton, and was presented to the Society by his daughter in December 1831 . No such portrait was ever given to the Royal Society. 
infantry regiment, raised (so the story went) at a cost of $£ 20,000$, serving abroad himself as a volunteer, and becoming (1780) lieutenant-colonel of the 87th Foot. When he settled in England, he enjoyed considerable social and political influence. A member of the Board of Agriculture, he was held in high repute as a practical and discerning landowner, most helpful in days of national difficulty. Loudon ("Encyclopædia of Agriculture", ed. 1825 and 1831) states that the cottages which the Earl of Winchilsea had built had a kitchen, parlour, dairy, and two bedrooms over; also there were several with small holdings attached of from 5 to 20 acres. $\mathrm{He}$ also encouraged the practice of letting portions of the pasture to labourers. Another custom was that the cottagers took small portions of farmers' fields to use as gardens-an early step towards our modern allotment system. At the time of the Napoleonic threat of invasion he embodied and commanded, in 1803, a volunteer corps. He was invested a Knight of the Garter in 1805.

Winchilsea was elected into the fellowship of the Royal Society in 1807 , signing the charter book the following year. In 1822, he accompanied GeorgeIV. on his Scottish tour. Hewas unmarried; and we like to think that he may have made the acquaintance of the youth, Faraday, who entered the service of the laboratory (1813) in the year that he vacated the presidential chair that he had so long occupied.

Empowered with authority for the introduction of a scheme of philosophical lectures, which, in due course, would be continued in a specially designed theatre, Count Rumford was not long in taking decisions respecting a beginning. In 1799 , he made inquiries of Thomas Garnett, M.D., then occupying a professorship in the Andersonian Institution, Glasgow, and very favourably known for his successful experimental presentation of philosophical subjects, for information respecting the plan of courses at that centre.

At the time, these men had never met each other. However, Rumford was sufficiently satisfied with the past and present qualifications of Garnett to make him an offer to transfer to London. Accordingly, Garnett resigned office in October 1799, and was appointed, with managerial approval, the first professor of natural philosophy and chemistry in the Royal Institution. It was certainly the belief of Garnett (a widower) that he and his children would be housed in Albemarle Street*; further, that he would be allowed to practise as a physician. But in these matters Rumford seems to have made arbitrary reservations. Notwithstanding these preliminary drawbacks, Dr. Garnett engaged with the utmost zeal in a series of morning and evening lectures, which proved highly attractive, and at which there were crowded audiences. But an incident of significant import for the professor reveals itself in the terms of a letter from Rumford to Sir Joseph Banks, dated May 29, 1800 :

I am very sorry to find, on making enquiry of Dr. Garnett, that your information was accurate respecting his having ascribed the late discoveries of our friend Volta to the French. . . . I have, however, insisted on its being rectified as far as it is possible, in some future lecture.

This letter was followed the next day by another from Count Rumford, stating that Dr. Garnett proposed to rectify his error, in the subjoined terms :

Having by mistake, on Wednesday, in the course of my public lecture ascribed to the French philosophers a new and interesting discovery relative to galvanism, which, on enquiry, I find belongs to Professor Volta, of Milan, I feel it to be my duty to state this fact in a public manner, in order that Professor Volta may not be deprived in any degree of the honour of a discovery which so justly which arrived in this country in the beginning of last month, was communicated to the president of the Royal Society. . . .

In all likelihood, Dr. Garnett would have set the matter in its proper light without the despotic action of Rumford. There is every warrant in the circumstances of his temperament and career for this assumption.

A scheme drawn up by Garnett for a full course of lectures in 1801 became a final stumbling-block. At a meeting of the authorities on Feb. 2, 1801, they resolved that the lectures should commence

* Count Rumford himself had quarters in the Institution's house at this period.

No. 3229, VoL. 128] 
as soon as the new theatre could be got ready for them, and that Count Rumford be authorised " to take all such steps on the part of the managers as shall be necessary in that business", and that Sir Joseph Banks, Henry Cavendish, and Count Rumford act as a committee to superintend the drawing up and publication of a suitable syllabus. It was further resolved that no syllabus of lectures or other account of what is doing or done, or to be done, at the Royal Institution be published by any person or persons without the permission of the aforesaid committee, or the express leave of the managers, signified in writing.

There was thus a fresh stranglehold, and Garnett was unequal to the occasion. On Feb. 16, 1801, the above decisions were communicated to $\mathrm{Dr}$. Garnett, and at the same time it was decided to engage Mr. Humphry Davy as assistant lecturer on chemistry, director of the Chemical Laboratory, and assistant editor of the Journals. He was to be allowed to occupy a room in the house, and be furnished with coals and candles. It is noteworthy that both Banks and Rumford were present when these courses were adopted.

\section{The Royal Institution in 1800.}

A glimpse of internal arrangements in which our forerunners participated may be of interest. Early there were set apart two reading-rooms, in addition, a "Conversation Room". In the former, various scientific periodicals, home and foreign, were available, and it was claimed that effectual measures were in force for securing continental issues without delay ; that, indeed, they frequently came to Albemarle Street "whilst yet wet from the press". The "Conversation Room" (so inscribed over the door) was supplied with a collection of maps "to assist agreeable talk". Major James Rennell assisted in this daring venture. Also, it was possible for frequenters to obtain, "at the most reasonable prices ", from the housekeeper's quarters below, soups of various kinds, tea, coffee, chocolate, and what were euphemistically designated "other refreshments"

The clerk was enjoined to be constantly provided with writing-paper of all kinds, and pens and ink. As to letters, these were taken away every evening for the General Post, by a postman who, at stated hours, was wont to pass along the street with a clanging bell to proclaim his mission. The Royal Institution paid the postman one guinea a year for call services in lieu of the usual allowance of one penny for each letter, and hence it was not necessary for members to put money into the hall post-box with their letters. Such, then, were the postal and other facilities enjoyed at the Royal Institution in 1800.

In 1801, Count Rumford reported that a complete kitchen for a small family, with a roaster of simple construction, a cottage fireplace grate, and a small boiler with steamers had been installed in the housekeeper's room, and these could be examined by callers. A principal kitchen was promised of larger order, to contain many novel fixtures, and to be open for demonstrations. The merit of any new method of cooking or of any new prepared dish might be judged from the actual experiment. Accordingly, a dining-room was in view in which the managers might order " experimental dinners" to which the proprietors and subscribers could be invited ; the attendant expense to be defrayed by " those who partake of them".

In this year, too, as if through other hands, mention is made of the provision of some elegant bookcases, intended to shelve the library gifts of friends of the Institution. The managers welcomed donations, save works of professedly political tendency; whilst in each volume entry was made of the name of the donor, and date, on the ground that "it was agreeable to the principles of justice and to those of an enlightened policy not to forget acts of generosity ". The Journal for 1802 contains an interesting classified catalogue of the library thus far established.

\section{YoUng AND DaVY.}

In July 1801, Dr. Thomas Young, fortified with the recommendation of Sir Joseph Banks, and reported by Count Rumford as " a man of abilities equal to these undertakings", was instituted professor of natural philosophy, editor of the Journals, and superintendent of the house, with rooms. Rumford went elsewhere, but his control was not withdrawn. Young had been elected a fellow of the Royal Society in 1794, at the early age of twenty-one years. His reputation in the world of science and also in Egyptian hieroglyphics is well known.

Young did not remain long in his post, resigning in 1803. It has been handed down, on authority, that he was not successful as a lecturer to mixed audiences. A medallion in Westminster Abbey by Chantrey commemorates this gifted man. It is regrettable that Young is not represented at the National Portrait Gallery.

By this time many of the original schemes projected by Rumford, in particular the applications of science to domestic purposes, had suffered eclipse, through engendered passive resistance or chill indifference, and his authority and influence had waned. The school of mechanics, the workshops, the models, the kitchens became receding propositions - the lectures, laboratory, and library emphasised the Institution. The charter of a new and revised establishment awaited, however, the vision and genius of Humphry Davy. But if the old principles had been worn threadbare, they died hard. Thus, Banks to Rumford (1804): "It [the Royal Institution] is now entirely in the hands of the profane. I have declared my dissatisfaction at the mode in which it is being carried on, and my resolution not to attend in future." Again : "The Institution has irrevocably fallen into the hands of the enemy, and is now perverted to a hundred uses for which you and I never intended it. Adieu, then, Institution!" We realise that the parting of the ways had been reached. From the very start Banks had been a constant supporter of

No. 3229, VoL. 128] 
Rumford, though it is hard to believe that he passed all the coin as sterling.

Humphry Davy was knighted in 1812, created a baronet in 1818, and was elected president of the Royal Society in 1820 , following Wollaston. Drastic and fundamental changes in the management of the Royal Institution came about during Davy's time. They were consequent on his discoveries, his lectures, his outlook. There were many obstacles, many critics, and much need for philosophical serenity. In 1809 a report stated that "if the support of scientific men is to be obtained something must be done to give the Institution more the form of a public establishment than that of private and hereditary property ". It was not long before the decision was taken to seek parliamentary authority for an Act for altering and amending the charter. This received the Royal assent in 1810. A lecture, comprehending a new plan, by Davy, left nothing unsaid. We quote from his words :

Besides the diffusion of knowledge by popular philosophical lectures, and by other more elementary and more scientific lectures, the new plan will also embrace a design for the promotion of knowledge by experiments and original investigations.

Sir Humphry Davy married in 1812, and on April 5, 1813, he resigned the post of professor of chemistry and director of the Laboratory of the Royal Institution. It is recorded that on his resignation :

Earl Spencer moved: That the thanks of this meeting be returned to Sir Humphry Davy for the inestimable services rendered by him to the Royal Institution. The motion was seconded by the Earl of Darnley and agreed to unanimously.

Davy's merits were recognised further by his election as honorary professor of chemistry.

\section{Faraday.}

Michael Faraday, born in London in 1791 (which, as a matter of historic coincidence, was the year which marked the creation of Sir Benjamin Thompson, at the hands of the reigning Duke of Bavaria, Count von Rumford), sprang from the ranks of the humbler classes. His father was a working blacksmith, whose home, Jacob's Well Mews, when Faraday was a small child, was within a quarter of an hour's northerly walk of Albemarle Street. Drawn from a family of select and positive religious fervour, traits of this character tinctured the whole of Faraday's ultimate outlook on life and its obligations. Once he wrote, "In my intercourse with my fellow-creatures, that which is religious and that which is philosophical have ever been two distinct things ".

Faraday was equipped only with a scanty dayschool education, but he had an inquiring mind, strongly imbued in quite early youth with a love of books and what they could teach him ; moreover, he was full of curiosity regarding the very popular scientific discoveries of the period. We hear of his attendance at elementary philosophical lectures in his locality, and of making, in spare moments, simple experiments in chemistry and in electricity.

A member of the Royal Institution-a Mr. Dance -occupies a niche in history, for it was through his good offices that Faraday was enabled, by the merest friendly acquaintanceship extended to a frank, industrious, eager youth, to attend four of Sir Humphry Davy's last lectures in the theatre at Albemarle Street. Highly interested in all he saw and heard at these discourses, during which he made notes, and encouraged further by the same friend, he sent the script to Davy. The reply was encouraging. Faraday was then engaged in bookbinding work, and he had been able to secure some occupation in writing or copying from Davy at a time when the professor was injured in one of his eyes by an explosion of the lately discovered nitrogen chloride. Later on, Faraday himself did not escape the results of explosions. In the year 1812 , on Christmas Eve, there came a letter from Sir Humphry. In it he said :

I am far from displeased with the proof you have given me of your confidence, and which displays great zeal, power of memory, and attention. I am obliged to go out of town, and shall not be settled in town till the end of January; I will then see you at any time you wish. It would gratify me to be of any service to you; I wish it may be in my power.

In the following year matters took better shape. The post of assistant in the Laboratory had become vacant and Davy offered it to Faraday at a wage of $25 \mathrm{~s}$. a week, with two attic rooms at the skyline of the house. He was introduced to the managers as one of good habits, active and cheerful in disposition, and intelligent in manner. His duties were to assist the various lecturers and professors in preparing for, and during lectures; and he had instructions regarding cleaning, care of apparatus, models, and so on. Though only twenty-one or twenty-two, he seems to have held a watching brief amongst the faithful, little realised, we may be sure, by those on the floor of the theatre. Writing to a friend, he said :

The opportunities that I have had of attending and obtaining instruction from various lecturers in their performance of duties attached to their office, has enabled me to observe the various habits, peculiarities, excellencies, and defects of each of them, as they were evident to me during the delivery. I did not wholly let this part of the things occurrent escape my notice; but, when I found myself pleased, endeavoured to ascertain what had affected me; also, when attending to Mr. Powell or Mr. Brande in their lectures, observed how the audience were affected, and by what their pleasure and their censure was drawn forth.

Faraday left England in the autumn of 1813 in order to accompany Sir Humphry and Lady Davy on a European tour. They travelled in France, Italy, Switzerland, and the Tyrol, returning to London in April 1815. Re-engagement at the Royal Institution as assistant in the Laboratory happily followed, on increased monetary terms, and with apartments. On June 12, 1821, residence

No. 3229, VoL. 128] 
in the Institution having been arranged, Faraday married. In 1824 fellowship of the Royal Society was attained; also, in this year he joined the Geological Society, having interest probably more on the mineralogical side of the science than any other. Later, he served on its council. The outstanding event of 1825 was his election at the Royal Institution as director of the Laboratory and superintendent of the House; in that year, too, came his memorable discovery of benzene, announced to the Royal Society in a paper dated June 16, 1825.

By the time he was thirty-eight (1830), Faraday had accomplished a full measure of practical research. He was, moreover, on the threshold of establishing a physical link, namely, the connexion between electricity and magnetism. But he was ever alive to the needs of the Institution as a corporate body, and of its traditions. He kept continually in mind that the Royal Institution had objects of national importance to carry out; that it required sustaining energy, must be efficacious, and maintain its position, well defined years back by Davy. Apart from research, a great debt of gratitude for fulfilment is due therefore to Faraday, and must be part of the festival of thanks.

The inauguration of juvenile lectures and the discourses at Friday evening meetings were features of this period. At the former, those young people who cared to remain found Faraday ready to talk and explain. He had ease of his own in descending from the topmost rung of the ladder of science to convey in the minds of youthful listeners the scientific principles of "common things'.

Faraday's connexion with the Royal Society was, of course, close and distinctive. He was a member of council in 1830 when the choice for the chair lay between H.R.H. the Duke of Sussex and Sir John Herschel, the astronomer and physicist. In 1832 and again in 1838 he received the Copley medal for his discovery of magneto-electricity and for researches in specific electrical induction respectively. Royal medals were allotted to him in 1835 and 1846, also the Rumford medal (1846). He was on five occasions Bakerian lecturer. On the last of these (1857) the subject was " Experimental Relations of Gold (and other metals) to Light". His final contribution to the Society was "On Regelation", read on April 26, 1860. In this he referred to the work of Tyndall and others. The Royal Society invited him to be its president in succession to Lord Wrottesley, but he stood aside in fixity of purpose. Visitors at the forthcoming centenary celebrations will be able to see at the rooms of the Royal Society the canvas by E. Armitage, R.A., portraying a deputation thereon, in 1857.

As scientific adviser to the Trinity House for a long series of years, Faraday made numberless reports, and paid constant visits to lighthouses.

In 1861, when sixty-nine years of age, Faraday conceived that the end of his scientific pilgrimage was within sight. Hence, writing to the managers of the Royal Institution, he reminded them of forty-nine years' service. His life had been a happy one, and all he desired. In its progress he had tried to make fitting return to the Royal Institution, and through it to science. The course of time had given development, maturity; now he had to face gentle decay. The managers, however, desired his retention of office in such manner as might appear convenient to himself.

In 1866 Faraday received from the Society of Arts its Albert medal - “ "for discoveries in electricity, magnetism, and chemistry, which, in their application to the industries of the world have largely promoted Arts, Manufactures, and Commerce". This was, in all probability, the last British recognition of his achievements that life permitted him to receive. The Prince Consort, in compliance with the wishes of Queen Victoria, had placed a house at his disposal on Hampton Court Green. There Faraday died on Aug. 25, 1867.

\section{TrNDaLL.}

John Tyndall was a moving figure in philosophy and in those manifold applications of science which distinguished the nineteenth century, tokens of newness of ideas and newness of things. Chosen in May 1853 to be professor of natural philosophy at the Royal Institution, he was a colleague of Michael Faraday for fourteen years. In 1867 he succeeded the master at Albemarle Street, and his future career lay there, embracing in all thirty-four years. Throughout, he maintained a high reputation as a lecturer, writer, and publicist.

Tyndall was born in Ireland in 1820. His early education, though restricted, was broadly amplified through intensive individual effort. He was at the University of Marburg from 1848 until 1851. About this period a lifelong friendship began with T. H. Huxley. The publication of an essay on the cleavage of slate rocks was the proximate cause of his joining the latter in a visit to the glaciers of Switzerland in 1856 ; they issued afterwards a joint paper on the structure and motion of glaciers. For some years Tyndall was scientific adviser to the Trinity House and the Board of Trade, but he resigned these offices in 1883 . Elected a fellow of the Royal Society in 1852, he received the Rumford medal in 1864; and he was on four occasions Bakerian lecturer.

At his first Friday evening lecture at the Royal Institution, delivered on Feb. 11, 1853, Tyndall remarked that he had engaged in it "not without fear and trembling, for the Royal Institution was to me a kind of dragon's den where tact and strength would be necessary to save me from destruction". Many words of wisdom have been uttered from behind the lecture table of the Royal Institution. Words of Tyndall uttered in 1879, in a discourse on the electric light, are singularly appropriate to recall just now-" it is Faraday's spark which now shines upon our coasts, and promises to illuminate our streets, halls, quays, squares, warehouses, and, perhaps at no distant day, our bomes".

Tyndall died at Hindhead, near Haslemere, on Dec. 4, 1893. 